REVIEW

\title{
Spring viremia of carp (SVC)
}

\author{
W. Ahne ${ }^{1}$, H. V. Bjorklund ${ }^{2}$, S. Essbauer ${ }^{3, *}$, N. Fijan ${ }^{4}$, G. Kurath ${ }^{5}$, J. R. Winton ${ }^{5}$ \\ ${ }^{1}$ Institute of Zoology, Fishery Biology and Fish Diseases, Faculty of Veterinary Medicine of the Ludwig Maximilians \\ University of Munich, Kaulbachstrasse 37, 80539 Munich, Germany \\ ${ }^{2}$ Orion Pharma Animal Health, PO Box 425, 20101 Turku, Finland \\ ${ }^{3}$ WHO-centre for Comparative Virology, Institute of Medical Microbiology, Infectious and Epidemic Diseases, \\ Faculty of Veterinary Medicine of the Ludwig Maximilians University of Munich, Veterinaerstr. 13, 80539 Munich, Germany \\ ${ }^{4}$ Department of Biology and Pathology of Fish and Bees, Veterinary Faculty, University of Zagreb, Heinzelova 55, \\ PO Box 190, 10000 Zagreb, Croatia \\ ${ }^{5}$ Western Fisheries Research Center, 6505 NE 65th Street, Seattle, Washington 98115, USA
}

\begin{abstract}
Spring viremia of carp (SVC) is an important disease affecting cyprinids, mainly common carp Cyprinus carpio. The disease is widespread in European carp culture, where it causes significant morbidity and mortality. Designated a notifiable disease by the Office International des Epizooties, SVC is caused by a rhabdovirus, spring viremia of carp virus (SVCV). Affected fish show destruction of tissues in the kidney, spleen and liver, leading to hemorrhage, loss of water-salt balance and impairment of immune response. High mortality occurs at water temperatures of 10 to $17^{\circ} \mathrm{C}$, typically in spring. At higher temperatures, infected carp develop humoral antibodies that can neutralize the spread of virus and such carp are protected against re-infection by solid immunity. The virus is shed mostly with the feces and urine of clinically infected fish and by carriers. Waterborne transmission is believed to be the primary route of infection, but bloodsucking parasites like leeches and the carp louse may serve as mechanical vectors of SVCV. The genome of SVCV is composed of a single molecule of linear, negative-sense, single-stranded RNA containing 5 genes in the order 3'-NPMGL-5' coding for the viral nucleoprotein, phosphoprotein, matrix protein, glycoprotein, and polymerase, respectively. Polyacrylamide gel electrophoresis of the viral proteins, and sequence homologies between the genes and gene junctions of SVCV and vesicular stomatitis viruses, have led to the placement of the virus as a tentative member of the genus Vesiculovirus in the family Rhabdoviridae. These methods also revealed that SVCV is not related to fish rhabdoviruses of the genus Novirhabdovirus. In vitro replication of SVCV takes place in the cytoplasm of cultured cells of fish, bird and mammalian origin at temperatures of 4 to $31^{\circ} \mathrm{C}$, with an optimum of about $20^{\circ} \mathrm{C}$. Spring viremia of carp can be diagnosed by clinical signs, isolation of virus in cell culture and molecular methods. Antibodies directed against SVCV react with the homologous virus in serum neutralization, immunofluorescence, immunoperoxidase, or enzyme-linked immunosorbent assays, but they cross-react to various degrees with the pike fry rhabdovirus (PFR), suggesting the 2 viruses are closely related. However, SVCV and PFR can be distinguished by certain serological tests and molecular methods such as the ribonuclease protection assay.
\end{abstract}

KEY WORDS: Rhabdovirus · Spring viremia of carp virus · SVCV · Disease $\cdot$ Cyprinids · Carp · Fish disease Resale or republication not permitted without written consent of the publisher

\section{INTRODUCTION}

Dating back possibly to the Middle Ages, common carp Cyprinus carpio in European pond culture have been plagued by a complex of infectious diseases vari-

(C) Inter-Research $2002 \cdot$ www.int-res.com ously known as infectious dropsy, rubella, infectious ascites, hemorrhagic septicemia, and red contagious disease (Hofer 1904, Schäperclaus 1930, Tomašec et al. 1964, Bauer \& Faktorovich 1969). These diseases proved to be of great economical importance, causing

\footnotetext{
*Corresponding author.

Email: sandra.essbauer@micro.vetmed.uni-muenchen.de
} 
serious losses in carp pond fisheries of the central and eastern parts of Europe (Fijan 1972, 1999). The assumed causes (nutrition, environment, parasites, bacteria, viruses) for the acute and chronic forms of the epizootics remained controversial for a long time. However, a viral etiology for the acute form of infectious dropsy became evident when a cytopathic agent was isolated (Osadchaya 1964, Tomašec et al. 1964), and River's postulates were fulfilled using virus isolated from affected carp (Fijan et al. 1971). In order to distinguish the viral disease from other aetiological entities within the infectious dropsy complex, the disease was renamed 'spring viremia of carp' (SVC), and the causative virus was termed 'spring viremia of carp virus' (SVCV) or Rhabdovirus carpio (Fijan et al. 1971). The infectious disease of carp termed swim-bladder inflammation (SBI) was also recognized in Europe (Arshaniza et al. 1968, Otte 1972). A rhabdovirus isolated from carp exhibiting the acute form of SBI (Ahne 1973, Bachmann \& Ahne 1973, 1974) was found to be identical to $R$. carpio (de Kinkelin \& Le Berre 1974, Hill et al. 1975). Later, it was shown that the chronic disease termed 'carp erythrodermatitis' was caused by a bacterium of the genus Aeromonas (Bootsma et al. 1977). For more complete reviews of the history of these conditions, see Fijan (1999) or Wolf (1988).

In Europe, SVCV mainly affects the common carp Cyprinus carpio, but several other species of fresh water fishes can be infected (Fijan 1972, 1988, 1999, Wolf 1988). In carp, the most common external signs of SVC are hemorrhages of the skin, exopthalmia, abdominal distension, and an inflamed or edematous vent (Fig. 1A). Internal signs are peritonitis, ascites, catarrhal and hemorrhagic enteritis, edematous viscera and petechial hemorrhages of the internal wall of the swimbladder and in skeletal muscle (Fijan et al. 1971, Ahne \& Wolf 1977, Negele 1977).

A rhabdovirus isolated from penaeid shrimps in Hawaii (Lu et al. 1991) had a G gene that exhibited over $99 \%$ identity to the G nucleotide sequence of SVCV (Johnson et al. 1999). The agent caused histological changes and significant mortality in penaeid shrimps (Lu \& Loh 1994). The SVCV-like virus isolated from penaeid shrimp in Hawaii was reported to cause histological changes and mortalities in Penaeus stylirostris through experimental water-born infection, oral feeding and intramuscular injection of the virus (Lu et al. 1991).

\section{PROPERTIES OF SVCV}

SVCV exhibits the typical bullet-shaped morphology of a vertebrate rhabdovirus (Wunner et al. 1995) (Fig. 1B). The virion possesses an inner nucleocapsid with helical symmetry measuring about $50 \mathrm{~nm}$ in diameter. The virion measures approximately 80 to $180 \mathrm{~nm}$ in length and 60 to $90 \mathrm{~nm}$ in diameter. Truncated particles, about $2 / 3$ of the length of infective virions, represent defective, noninfectious virions (Fijan et al. 1971, Bachmann \& Ahne 1973, Hill et al. 1975, Bishop \& Smith 1977). SVCV has a buoyant density in $\mathrm{CsCl}$ of 1.195 to $1.200 \mathrm{~g} \mathrm{~cm}^{-3}$ (Bachmann \& Ahne 1973). Virus infectivity is destroyed at pH 3 and 12, by lipid
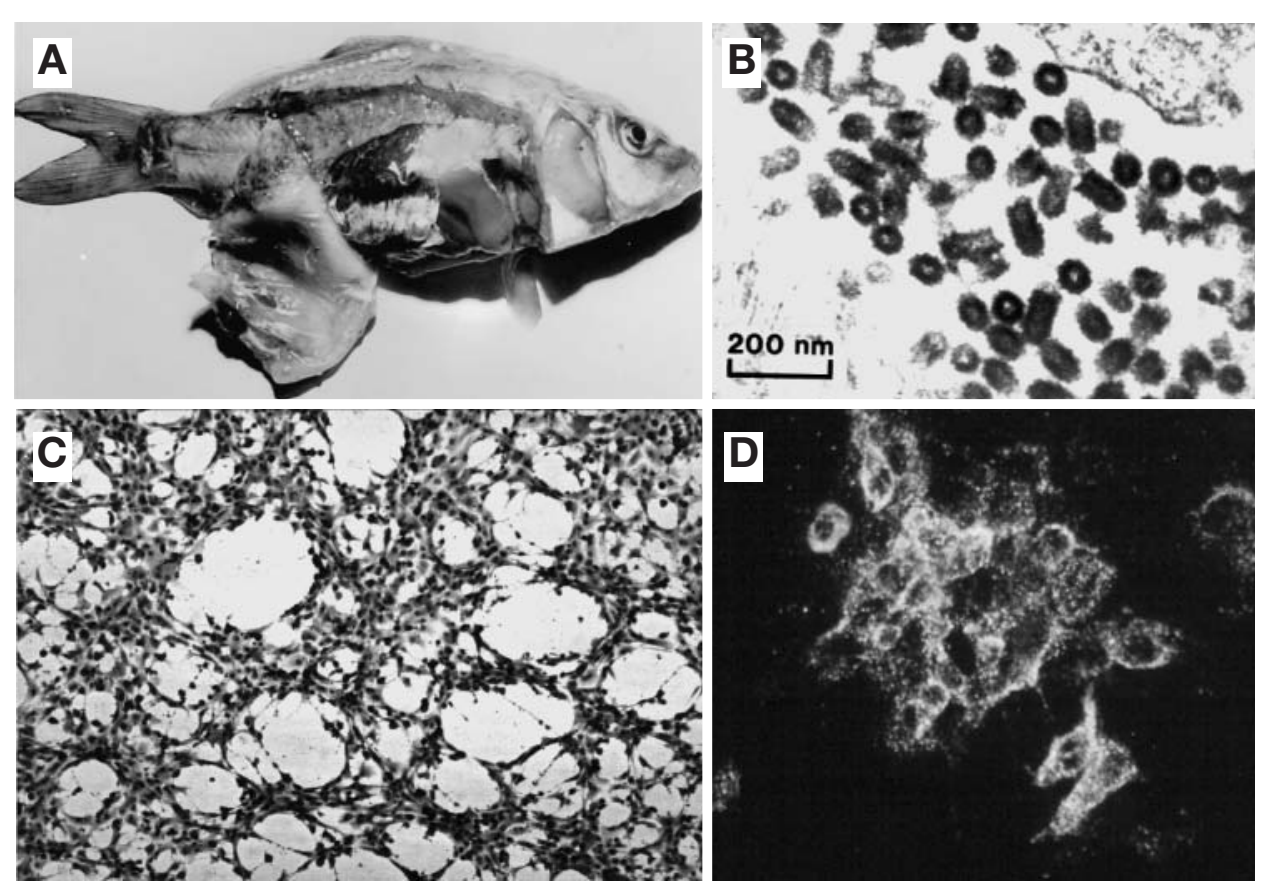

Fig. 1. (A) SVCV (spring viremia of carp virus)-infected common carp showing petechial hemorrhages in the muscles, swim bladder, enlarged spleen, edematous organs and pale gills with hemorrhages. (B) Electron micrograph of SVCV in infected fathead minnow (FHM) cells showing bullet-shaped particles. (C) Cytopathogenic effect (CPE) of SVCV in FHM cells, $72 \mathrm{~h}$ after infection, $20^{\circ} \mathrm{C}$. The CPE is characterized by rounding of cells and focal lysis of the monolayer (magnification: 206×). (D) Detection of SVCV antigen in FHM cells, $24 \mathrm{~h}$ post infection (p.i.) using indirect immunofluorescence (magnification: $860 \times$ ) 
Table 1. Features of the 5 genes of the spring viremia of carp virus (SVCV) genome. UTR: untranslated region; N: nucleocapsid; P: phosphoprotein; M: matrix protein; G: glycoprotein; L: polymerase. nt: nucleotides; aa: amino acids; mw: molecular weight; pI: isoelectric point. The last 3 columns refer to the protein predicted by translation of the open reading frames (ORFs) in the nucleotide sequence of the SVCV genome. Thus, the protein molecular weight is for the predicted product with no post-translational modification such as phosphorylation or glycosylation

\begin{tabular}{|lccccccc|}
\hline Gene & Total gene & Upstream & Downstream & ORF & Protein & Protein \\
length (nt) & UTR (nt) & UTR (nt) & Protein \\
(nt) & (aa) & (mw) & (pI) \\
\hline $\mathrm{N}$ & 1335 & 10 & 68 & 1254 & 418 & 47000 & 5.57 \\
$\mathrm{P}$ & 967 & 10 & 27 & 927 & 309 & 35622 & 4.46 \\
$\mathrm{M}$ & 716 & 10 & 34 & 669 & 223 & 25627 & 8.61 \\
$\mathrm{G}$ & 1588 & 10 & 48 & 1527 & 509 & 57338 & 5.54 \\
$\mathrm{~L}$ & 6325 & 10 & (trailer) & 6285 & 2095 & 238244 & 8.63 \\
\hline
\end{tabular}

the most abundant virion protein and interacts with the viral RNA to form the helical structure of the nucleocapsid, and also has an important role in modulating transcription. About $1 / 3$ of the $\mathrm{N}$ protein is associated with viral RNA (Sokol \& Koprowski 1975). The phosphoprotein ( $\mathrm{P}$ protein) is a component of the rhabdovirus nucleocapsid that, in association with the $\mathrm{L}$ and $\mathrm{N}$ proteins, is required for transcription (Wunner et al. 1975, Roy 1981). Like other vesiculoviruses, SVCV has one membrane protein (M protein). This basic protein forms the bullet-shaped structure of the virion and links the nucleocapsid with solvents, and by heat $\left(56^{\circ} \mathrm{C}\right)$. The virus is inactivated within $10 \mathrm{~min}$ by formalin (3\%), chlorine (500 ppm), iodine $(0.01 \%), \mathrm{NaOH}(2 \%), \mathrm{UV}(254 \mathrm{~nm})$ and gamma irradiation (103 krads). Freeze-thaw cycles partially inactivate the virus. During lyophilization, addition of 2 to $10 \%$ fetal calf serum protects the virus infectivity (de Kinkelin \& Le Berre 1974, Ahne 1976, 1982).

The virus is presently classified as a tentative member of the genus Vesiculovirus of the family Rhabdoviridae (Walker et al. 2000). As with other members of the genus, the virion of SVCV contains 5 structural proteins (now termed N, P, M, G, L), the sizes of which were initially estimated by mobility in SDS-PAGE (sodium dodecyl sulphate polyacrylamide gel electrophoresis) gels (Lenoir 1973, Lenoir \& de Kinkelin 1975, Clerx \& Horzinek 1978, Roy et al. 1984). Recently, the availability of sequence data for the entire SVCV genome allows more accurate predictions of the molecular weights of the structural proteins (ignoring post-translational modifications) as well as other features of these molecules (Table 1). The RNA-dependent RNA polymerase (L protein) functions in transcription and replication of the virus with an optimal temperature for activity between 20 and $25^{\circ} \mathrm{C}$ (Roy \& Clewley 1978). Virus transcription and replication is achieved as the $\mathrm{L}$ protein interacts with the $\mathrm{P}$ and $\mathrm{N}$ proteins of the nucleocapsid. The glycoprotein (G protein) of SVCV forms trimeric peplomers or spikes on the virus surface that bind to cellular receptors and induce viral endocytosis. The surface glycoprotein acts as the most important viral antigen that determines the serological properties of rhabdoviruses (Hill et al. 1975, Bishop \& Smith 1977, Jørgensen et al. 1989). The nucleoprotein ( $\mathrm{N}$ protein) is the cytoplasmic domains of the $\mathrm{G}$ protein embedded in the lipid-containing viral envelope (Walker et al. 2000) (Fig. 2).

\section{GENOMIC ORGANIZATION OF SVCV}

The SVCV virion contains 1 molecule of linear, negative-sense, single-stranded RNA that sediments in 5 to $20 \%$ sucrose gradients at 38 to $40 \mathrm{~S}$ (sediment coefficient) (Hill et al. 1975, Lenoir \& de Kinkelin 1975, Clerx \& Horzinek 1978, Roy \& Clewley 1978, Wu et al. 1987). Characterization of this SVCV genomic RNA began in 1984 with publications of the $M$ gene

\section{A svcV Virion}

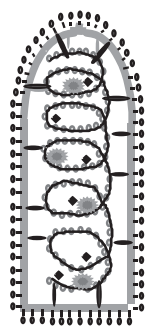

B SVCV Genome RNA (11,019 nt)

\begin{tabular}{|l|l|l|l|l|l||}
\hline $3^{\prime}$ & $\mathrm{N}$ & $\mathrm{P}$ & $\mathrm{M}$ & $\mathrm{G}$ & $\mathrm{L}$ \\
\hline
\end{tabular}

C conserved gene junction and upstream untranslated region:

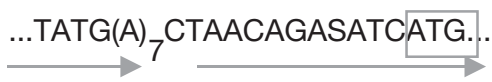

Fig. 2. Spring viremia of carp virus (SVCV). (A) Virion structure, (B) genomic organization, and (C) gene junction sequences of SVCV 
sequence and a 70 nucleotide sequence at the 3' genome terminus (Kiuchi \& Roy 1984, Roy et al. 1984). This line of investigation then lays apparently dormant until publication of the partial L gene, complete G gene, and gene junction sequences in 1995 and 1996 (Bjorklund et al. 1995, 1996). In 2001, 2 complete genomic RNA sequences of an American type culture collection (ATCC) reference strain of SVCV (VR-1390) were submitted to GenBank by independent laboratories (GenBank accession U18101 by Bjorklund et al. 1996 and GenBank accession AJ318079 by Hoffman et al.). With this data now available, the genetic organization of SVCV can be definitively described. The genomic RNA is 11019 bases in length. It contains 5 major open reading frames (ORFs), encoding predicted proteins homologous to the 5 major structural proteins found in all rhabdoviruses. The genomic order is $3^{\prime}$ NPMGL-5', as shown in Fig. 2B. This is identical to the genetic organization of species in the genera Vesiculovirus and Lyssavirus. This confirmed gene order for SVCV clarifies any confusion resulting from an early publication that suggested an alternative organization (Wu et al. 1987). The SVCV genome does not have a non-virion (NV) gene between the G and L genes as is found in fish rhabdoviruses of the genus Novirhabdovirus (Kurath et al. 1997, Walker et al. 2000). Similarly, it does not have a large non-coding region between the $\mathrm{G}$ and $\mathrm{L}$ gene ORFs, as is found in lyssavirus genomes. Thus, the overall genome structure of SVCV is most similar to that of the Vesiculovirus genus.

The SVCV genome has a 59 base putative leader region at the 3 ' terminus followed by a consensus start signal (AACAG; mRNA-sense) for transcription of the $\mathrm{N}$ gene. Analysis of the SVCV N-gene mRNA by 5' RACE (rapid amplification of cDNA ends) has confirmed that transcription starts at this AACAG signal (W. Batts \& G. Kurath unpubl.). The features of the 5 genes and their protein products are summarized in Table 1. Other than the 5 major ORFs, only one is longer than 50 amino acids in the standard rhabdovirus orientation (53 amino acids, within the M gene), and there are several in the reverse orientation, all less than 140 amino acids. It is not known whether any of these small ORFs are expressed, and there is no indication of an overlapping reading frame within the $\mathrm{P}$ gene encoding a small basic protein, as has been reported for vesicular stomatitis New Jersey virus (VSNJV) (Spiropoulou \& Nichol 1993).

As described by Bjorklund et al. (1996), the 4 SVCV gene junctions are strictly conserved, with a TATG(A)7 transcription stop/polyadenylation signal at the end of each gene, and an AACAG transcription start signal for the following gene. The untranscribed intergenic regions of SVCV are all dinucleotides (CT), with the exception of the G-L gene junction which has a tetranucleotide (CTAT). These regulatory signals and intergenic regions are highly conserved between SVCV and all vesiculoviruses, and they differ from the gene junctions of viruses in other rhabdovirus genera such as lyssaviruses or novirhabdoviruses. However, unlike other vesiculoviruses that have been characterized to date, the untranslated regions upstream of all $5 \mathrm{SVCV}$ genes are completely uniform, consisting of exactly 10 nucleotides preceding the ATG-codon signaling the start of translation (Table 1). The sequence of this 10-base region begins with the recognized vesiculovirus pentanucleotide transcription start signal and is highly conserved between the gene junctions: 4 of the SVCV genes $(N, M, G, L)$ begin with the sequence AACAGACATC, and only the $\mathrm{P}$ gene has a single nucleotide difference making it AACAGAGATC. Although the length of the upstream untranslated regions is variable among other vesiculovirus genes, they begin with a consensus sequence AACAGNNATC (Luis L. Rodriguez, USDA Plum Island Animal Disease Center, pers. comm.), which matches the conserved SVCV sequence at 8 out of 10 sites. This identity at the $3^{\prime}$ termini of the genes provides confirmation for an early comparison of transcript termini of SVCV and vesicular stomatitis Indiana virus (VSIV) that suggested conservation of the rhabdoviral genome sequences specifying the 5' ends of transcript RNAs (Gupta et al. 1979). The transcription stop/polyadenylation signal for the SVCV L gene is followed by a 46 base trailer that forms the 5' terminus of the genome.

Sequence similarities between SVCV and vesicular stomatitis viruses were first reported in 1984 using complete $\mathrm{M}$ gene and 3' terminal genome sequences (Kiuchi \& Roy 1984, Roy et al. 1984). The 3'-terminal 20 nucleotides were found to be nearly identical to the corresponding sequences of both VSIV and VSNJV. Later, comparisons of the first 1780 amino acids of the predicted SVCV L protein with partial L proteins of other rhabdoviruses revealed closest homology with the VSIV polymerase, although significant homology was also found with the polymerase of rabies virus (Bjorklund et al. 1995). The homologies involved several highly conserved domains separated by variable regions. The conserved domains most likely represent previously identified RNA polymerase functional domains such as those for RNA binding, RNA template recognition, phosphodiester bond formation, and ribonucleotide triphosphate binding (Poch et al. 1990). There was very little similarity between the L proteins of SVCV and the novirhabdovirus, infectious hematopoietic necrosis virus. The SVCV G gene encodes a 509 amino acid protein with a predicted structure similar to other rhabdovirus glycoproteins (Bjorklund et al. 1996). It contains 2 major hydrophobic domains 
including the signal peptide and transmembrane domain. The complete SVCV G protein was most closely related to members of the Vesiculovirus genus, showing 31.2 to $33.2 \%$ amino acid identity (51.8 to $53.3 \%$ amino acid similarity) with VSIV, VSNJV, and Chandipura virus (CHPV). In contrast, there was only 19.4 to $24.3 \%$ amino acid identity (40.5 to $47.2 \%$ amino acid similarity) with $\mathrm{G}$ proteins of 11 rhabdoviruses from other genera.

Phylogenetic analyses (Fig. 3) using the full-length amino acid sequences of the N, P, M, and G proteins, as well as partial sequences of the L proteins, confirms the close relationship between SVCV and the established members of the Vesiculovirus genus (Bjorklund et al. 1996, Johansson 2001). Examples of such phylogenetic trees are shown in Fig. 3 for fulllength $\mathrm{G}$ and $\mathrm{N}$ protein sequences. Despite minor differences in topology between the trees generated by the different genes, both indicate a close phylogenetic relationship between SVCV and accepted members of the Vesiculovirus genus. This is supported by significant bootstrap values, providing a high level of confidence in this relationship. The 7 th report of the International Committee for Virus Taxonomy lists SVCV as a tentative member of the Vesiculovirus genus (Walker et al. 2000). In the future, data including thorough phylogenetic analyses will be used in support of a proposal that SVCV belongs within this genus as a full member, as has been suggested previously (Bjorklund et al. 1996).

Within the species SVCV, the genetic diversity among SVCV strains has been demonstrated by biological and serological analyses (Jørgensen et al. 1989) and by ribonuclease protection assays (Ahne et al. 1998). Although there are not yet any published reports characterizing sequence diversity between strains, this is an area of active investigation in several laboratories.
A) N Proteins

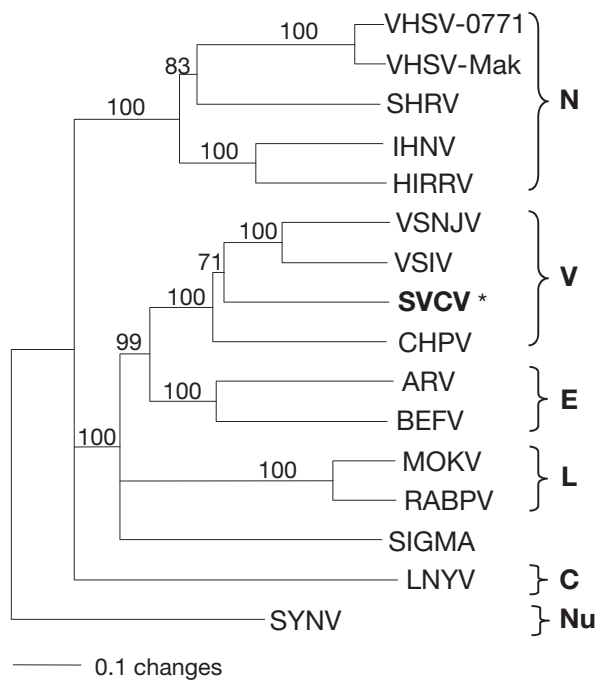

B) G Proteins

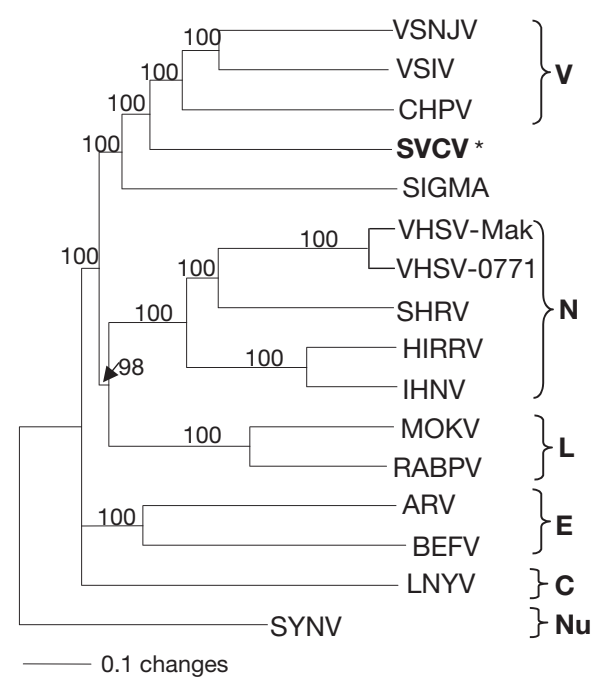

Fig. 3. Phylogenetic relationships of (A) nucleocapsid and (B) glycoprotein gene sequences of spring viremia of carp virus (SVCV) and 15 other rhabdoviruses. The viral species and the GenBank sources for their N and G amino acid sequences were: SVCV (U18101); vesicular stomatitis New Jersey virus (VSNJV, K02379, J02433); vesicular stomatitis Indiana virus (VSIV, J02428); Chandipura virus (CHPV, M16608, J04350); viral hemorrhagic septicemia virus, strain 0771 (VHSV-0771, AJ233396); viral hemorrhagic septicemia virus, strain Makah (VHSV-Mak, X59241, U28747); infectious hematopoietic necrosis virus (IHNV, L40883); hirame rhabdovirus (HIRRV, AF104985, U24073); snakehead rhabdovirus (SHRV, AF147498); rabies virus, Pasteur vaccine strain (RABPV, M13215); Mokola virus (MOKV, Y09762, S59447); Adelaide River virus (ARV, U10363, L09207); bovine ephemeral fever virus (BEFV, AF234533); Sigma virus (SIGMA, X91062); lettuce necrotic yellows virus (LNYV, L30103, AJ251533); and sonchus yellow net virus (SYNV, L32603). Sequences were aligned using Clustal X (Thompson et al. 1997) and analyzed with PAUP* 4.0 (Swofford 2000) neighbor-joining (shown) and parsimony phylogeny programs (not shown). Sequences from the plant rhabdovirus SYNV were used to outgroup the analyses. Each tree represents the consensus of 1000 bootstrapped replicates of the data, with bootstrap confidence values along the branches to indicate the percent of 1000 trees that contained exactly the grouping shown to the right of the value. Branches with bootstrap values less than 70 were collapsed to avoid suggesting uncertain relationships. The viral species included represent the 6 accepted rhabdovirus genera and 1 unassigned species (Sigma virus). Genera are indicated by brackets labeled as follows: V, Vesiculovirus; N, Novirhabdovirus; L, Lyssavirus; E, Ephemerovirus; C, Cytorhabdovirus; $\mathrm{Nu}$, Nucleorhabdovirus. Note that the position of SVCV (in bold and asterisked) relative to the 3 accepted members of the Vesiculovirus genus (VSNJV, VSIV, and CHPV) suggests that SVCV should be included in this genus 


\section{IN VITRO MULTIPLICATION OF SVCV}

SVCV replicates in cell cultures originated from fish, birds and mammals between 4 and $31^{\circ} \mathrm{C}$ (Ahne 1973, Clark \& Soriano 1974). Cytopathic effects (CPE), like margination of nuclear chromatin followed by rounding up and lysis of cells (Fig. 1C), appear at varying times of infection depending on the temperature and cell lines used. The optimal temperature of viral replication in vitro is between 20 and $25^{\circ} \mathrm{C}$. The best cell systems for multiplication of SVCV are those derived from cyprinid fishes (e.g. primary cell cultures or established cell lines) such as the epithelioma papillosum cyprini (EPC) cell line (Fijan et al. 1983), the fathead minnow (FHM) cell line (ATCC CCL-42, Gravell \& Malsberger 1965), and carp leukocyte cultures (CLC, European Collection of Cell Cultures 95070628, Faisal \& Ahne 1990). Using these cell lines, infectivity titers of about $10^{8} \mathrm{TCID}_{50}$ $\mathrm{ml}^{-1}$ were obtained regularly. Actinomycin D does not affect SVCV replication (de Kinkelin \& Le Berre 1974). The virus forms well-defined plaques in permissive cells $72 \mathrm{~h}$ after infection. A single step growth curve carried out in FHM cells at $20^{\circ} \mathrm{C}$ showed that the first progeny virus is synthesized 4 to $6 \mathrm{~h}$ after infection. Both cell-associated and cell-free virus reach peak titers between 10 and $22 \mathrm{~h}$ after infection. One growth cycle of the virus lasts 8 to $10 \mathrm{~h}$ at $20^{\circ} \mathrm{C}$ (Ahne 1973, Bachmann \& Ahne 1974). SVCV also replicates in chicken embryo fibroblasts, in mammalian cells such as BHK 21 (hamster), fetal calf kidney (cattle), HEP-2 (human), MDCK (canine), SK (porcine), Vero (monkey) and in several reptilian cell lines, provided that incubation temperatures between 20 and $22^{\circ} \mathrm{C}$ are used (Ahne 1973, Bachmann \& Ahne 1974, Clark \& Soriano 1974). It has been demonstrated that apoptosis is involved in death of EPC cells caused by SVCV (Bjorklund et al. 1997). Morphological changes, like reduction of cell volume, blebbing, and formation of apoptotic bodies, appear $36 \mathrm{~h}$ after infection of cells. About $40 \mathrm{~h}$ later, more than $70 \%$ of the SVCV-infected EPC cells were found to be apoptotic. It is likely that the programmed cell death of the SVCV-infected cells depends on replication and production of progeny virus. Apoptosis could be inhibited by the endogenous acid cysteine proteinase inhibitor, cystatin $\mathrm{A}$, which has been purified from human palatine tonsils (Bjorklund et al. 1997). Experiments showed that SVCV-induced apoptosis can also be inhibited by z-VAD-fmk, an inhibitor of caspase 1, 3, 4 and 7 (Taehtinen et al. unpubl.).

\section{ANTIGENIC PROPERTIES OF SVCV}

Several studies showed that carp develop a humoral immune response to SVCV (Sulimanović 1973, Kölbl
1975, Fijan et al. 1977a,b, Baudouy 1978, Ahne 1980, Baudouy et al. 1980a,b, Fijan \& Matašin 1980, Fijan 1988). Rhabdovirus-neutralizing antibodies are directed against the surface glycoprotein of the virus (Kelly et al. 1972). Induction of humoral antibodies against SVCV in carp is influenced by the age and condition of carp, by the route of infection and, most importantly, by the temperature of water (Fig. 4). In carp which were infected by waterborne exposure to low doses of SVCV and kept at $20^{\circ} \mathrm{C}$, SVCV neutralizing antibodies appeared $7 \mathrm{~d}$ after infection. In contrast, carp infected in the same way, but kept at $13^{\circ} \mathrm{C}$, showed first detectable antibodies $7 \mathrm{wk}$ after infection. At $13^{\circ} \mathrm{C}$, carp developed a subclinical infection with presence of virus in the blood of carp for about $10 \mathrm{wk}$. Neutralizing antibodies which appeared 8 to $10 \mathrm{wk}$ after infection lead to a rapid decline of the amount of virus in the blood (Ahne 1979, 1980, 1986). The biological properties of the SVCV neutralizing antibodies have not been studied in detail, but probably resemble the tetrameric antibody typically found in teleost fishes (Fijan et al. 1977a, Kaattari \& Piganelli 1996).

Cross-neutralization studies using the fish rhabdoviruses, infectious hematopoietic necrosis virus (IHNV), viral hemorrhagic septicemia virus (VHSV), hirame rhabdovirus (HIRRV) and their respective antisera, revealed no antigenic relationships between SVCV and these members of the Novirhabdovirus genus of the Rhabdoviridae (de Kinkelin \& Le Berre 1974, de Kinkelin et al. 1974, Hill et al. 1975). However, serological examination of 22 rhabdovirus isolates from

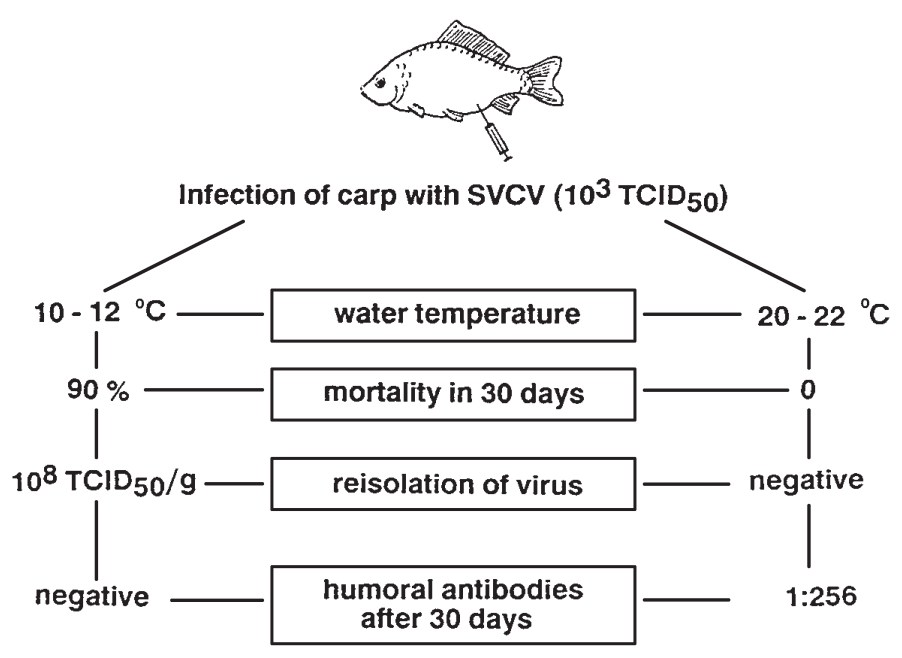

Fig. 4. Influence of water temperature on SVCV (spring viremia of carp virus)-infection of carp Cyprinus carpio leading to virus multiplication $\left(10\right.$ to $12^{\circ} \mathrm{C}$ ) or to production of antibodies $\left(20\right.$ to $22^{\circ} \mathrm{C}$ ). SPF carp (25 to $30 \mathrm{~g}$ ) were intraperitoneally infected with $10^{3} \mathrm{TCID}_{50}$ of SVCV. Infected fish kept at 10 to 12 and 20 to $22^{\circ} \mathrm{C}$ were analyzed for values of virus, antibodies and death (Ahne 1980) 
Cyprinidae, Esocidae and Siluridae indicates close relationship between SVCV and the vesiculovirus-like fish rhabdovirus, pike fry rhabdovirus (PFR, Jørgensen et al. 1989). These authors showed that SVCV and PFR cross-reacted by indirect immunofluorescence (Fig. 1D) using polyclonal antisera and shared common antigenic determinants on the $\mathrm{G}, \mathrm{N}$ and $\mathrm{M}$ proteins as revealed by immunoblotting. The 2 viruses could, however, be differentiated by neutralization assays using certain polyclonal antisera in the absence of complement. Consequently, it was suggested that SVCV and PFR should be considered as representatives of 2 serotypes of 1 virus species (Jørgensen et al. 1989). The 2 viruses could also be differentiated by a ribonuclease protection assay using a probe made from transcripts of the G gene of SVCV (Ahne et al. 1998), indicating that genetic differences exist between the 2 viruses. Resolution of the biological and genetic relationships between isolates of SVCV and PFR is important because isolation of SVCV from fish is notifiable to the Office International des Epizooties (OIE) while PFR is not.

\section{EXPERIMENTAL INFECTION OF CARP WITH SVCV}

The systemic character of SVCV infection has been demonstrated by experimental infection of specific pathogen free (SPF) carp (Ahne 1977, 1978). Following waterborne infection of carp at $13^{\circ} \mathrm{C}$, the virus was initially detected in the gills, suggesting they were the first targeted organ. Following an eclipse-like period of $4 \mathrm{~d}$, SVCV was spread via blood to the internal organs of infected fish. Eleven days after infection, SVCV was excreted from the alimentary tract in the feces and mucous casts. First mortality due to SVCV infection appeared $20 \mathrm{~d}$ after infection. The incubation period of the waterborne SVCV infection was found to be $7 \mathrm{~d}$ under the experimental conditions used (Fig. 5). First clinical signs such as edematous viscera, peritonitis, enteritis and hemorrhages in different organs could be recognized 8 to $11 \mathrm{~d}$ after infection. The virus persisted in infected carp for more than $10 \mathrm{wk}$ and those fish became SVCV carriers (Ahne 1977, 1978, 1980).

\section{HISTOPATHOLOGY OF SVC}

Precise reports on histological changes of SVCV-infected carp are rare. The following histological findings have been obtained in experi- mentally infected carp fingerlings (Negele 1977). The range of alterations of the liver went from perivasculitis showing lymphocytes and histiocytes infiltration, to panvasculitis with a high grade of edematization and a concurrent loss of structure of blood vessel walls. The blood vessels appeared to be fully necrotic in the final stage of the disease. The liver parenchyma showed multifocal necroses, adipose degeneration and hyperemia. In the pancreas, non-purulent inflammation and multifocal necrobiosis were usually seen. In the parietal and visceral serosa of the peritoneum, peritonitis was predominant. Lymph vessels were extremely dilated and filled up with detritus, macrophages, and

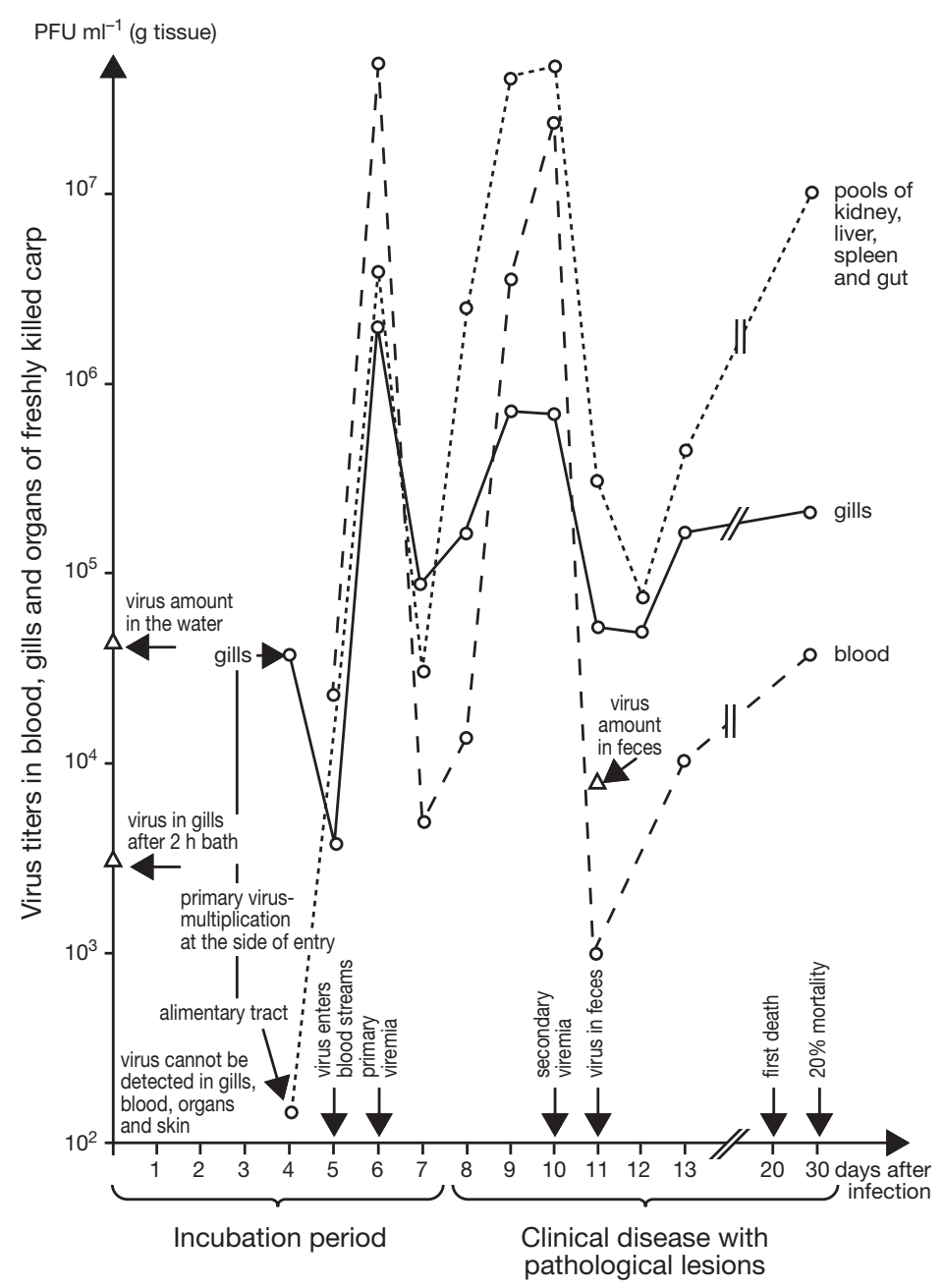

Fig. 5. Spread of spring viremia of carp virus (SVCV) through the body of carp Cyprinus carpio after waterborne infection for $2 \mathrm{~h}$ at $13^{\circ} \mathrm{C}$. SPF (specific pathogen free) carp (25 to $30 \mathrm{~g}$ ) were bathinfected with $10^{4.4}$ plaque-forming units (PFU) $\mathrm{ml}^{-1}$ of SVCV by waterbath at $13^{\circ} \mathrm{C}$. Two hours after infection, SVCV was detected only in the gills. After a $4 \mathrm{~d}$ eclipse period, progeny viruses were dessimated to internal organs via the bloodstream. Two viremia stages were recognized 6 and $10 \mathrm{~d}$ after infection. The incubation period lasted $7 \mathrm{~d}$ at $13^{\circ} \mathrm{C}$ (Ahne 1978) 
lymphocytes. In the intestine, perivascular inflammation and desquamation of epithelium with a subsequent atrophy of the villi have been often recognized. The spleen was hyperemic and showed a considerable hyperplasia of the reticuloendothelium. Siderocytes and cells with increased lipofuscin storage were present. The tubuli of the kidney were clogged by the tube casts, and vacuolation and hyaline degeneration were present. The lamina epithelia of the swim bladder changed into a discontinuous multilayer and in the submucosa dilated vessels and hemorrhages were evident. The heart showed discontinuous myodegeneration and inflammatory alterations of the pericardium.

\section{NATURAL OUTBREAKS OF SVC}

SVC is reported to be present in several European countries (Austria, Bulgaria, France, Germany, Great Britain, Hungary, Italy, Spain, as well as in parts of the former Czechoslovakia, Soviet Union and Yugoslavia; Tomašec et al. 1964, Fijan et al. 1971, Ghittino et al. 1971, Ahne 1973, Baudouy 1975, Kölbl 1975, Tesarčik et al. 1977, Bucke \& Finlay 1979, Roudikov 1980, Békési \& Csontos 1985, Shchelkunov \& Shchelkunova 1989, Marcotegui et al. 1992). In those countries, SVCV has economic significance in carp pond cultures. Mortality rates of young carp due to SVC can reach up to $70 \%$ during spring time outbreaks, but the yearly losses of older fish are usually below 30\%. Outbreaks of SVC depend on the temperature of the water, age and condition of fish, population density, and stress factors. SVCV-infected carp in ponds tend to concentrate around the water inlet. Reactions to sensory stimulation, swimming speed, and the respiration rate are slowed down progressively; lethargy, resting and leaning mark the terminal stage of disease. External signs of SVC under natural conditions are darkening of the skin, distended abdomen, exophthalmia, petechial hemorrhages in the skin, gills and eyes, inflamed and edematous vent, and pale gills. Internally, hemorrhages in the swim bladder, edematous organs, ascites and catarrhal enteritis are usually seen. Secondary and concomitant bacterial and/or parasitic infections can affect the mortality rate and symptoms (Fijan 1972). Patterns of the disease are influenced by the mentioned environmental factors as well as by unspecific (interferon) or specific immunity (humoral antibodies, cellular immunity). Clinical disease dominates at water temperatures between 5 and $10^{\circ} \mathrm{C}$, where the host immune response is usually suppressed or delayed. However, the lethal outcome is faster at temperatures between 10 and $17^{\circ} \mathrm{C}$, and fry can be affected at temperatures as high as 22 to $23^{\circ} \mathrm{C}$. SVCVinfected carp develop interferon within $24 \mathrm{~h}$, and virus neutralizing antibodies appear about $1 \mathrm{wk}$ after infection at $20^{\circ} \mathrm{C}$. Immune fish undergo a solid specific resistance against reinfection. The persistence of SVCV antibodies may vary individually from a few to several months (Fijan et al. 1977a, Baudouy 1978, Ahne 1979, Fijan 1988).

\section{EPIZOOTIOLOGY OF SVC}

The common carp Cyprinus carpio is the main host of SVCV (Fijan 1999). The virus affects carp at all ages but victims are mostly young fish. Natural outbreaks of SVC were also found in koi carp C. carpio, crucian carp Carassius carassius, big head Hypophthalmichthys molitrix, silver carp Aristichthys nobilis and sheatfish Silurus glanis (Fijan et al. 1984, Jørgensen et al. 1989, Shchelkunov \& Shchelkunova 1989, Ahne et al. 1998). Grass carp Ctenopharyngodon idella, Guppies Lebistes reticulatus, northern pike Esox lucius, pumpkinseed Lepomis gibbosus and roach Rutilus rutilus proved to be susceptible to SVCV by experimental infection (Ahne 1973, 1985b, Fijan 1988, Haenen \& Davidse 1993). SVCV can persist in asymptotic broodstock carp (Békési \& Csontos 1985). Reservoir hosts include sick fish and carp which survive epizootics, as well as other cultured or wild fish that may serve as carriers of SVCV. Possible biological vectors include the carp louse Argulus foliaceus and leeches Piscicola geometra, as well as fish-eating birds such as herons (Pfeil-Putzien 1977, Ahne 1985a, Peters \& Neukirch 1986). It was demonstrated that the fruit fly Drosophila melanogaster multiplied SVCV under experimental conditions (Bussereau et al. 1975). While the role of strictly terrestrial insects in the transmission of SVCV is unlikely, aquatic arthropods may be able to function as SVCV vectors. The SVCV-like agent isolated from shrimp in Hawaii replicated and caused histological changes in such crustaceans (Lu \& Loh 1994).

Generally speaking, transmission of SVCV is horizontal. Excretion of SVCV via feces and urine from infected fish has been demonstrated. The excreted virus could stay infective in the water for more than $4 \mathrm{wk}$ and in mud for about $6 \mathrm{wk}$ at 4 to $10^{\circ} \mathrm{C}$. An additional source of infection may be contaminated equipment (Ahne 1977, 1979, 1982). Several studies suggest that vertical transmission of SVCV is not an important source of infection (Ahne 1979, Békési \& Csontos 1985, Fijan 1988, 1999).

\section{DIAGNOSIS OF SVC}

SVC can be expected to cause mortalities in carp aquaculture at temperatures below $20^{\circ} \mathrm{C}$, especially in 
the spring. The behavior and external signs in easily caught moribund fish exhibiting hemorrhages in skin, pale gills, ascites, etc., warrant necropsy and further sampling of fish for virological examination. Presumptive diagnosis is based on the presence of enteritis, peritonitis, edema, petechial bleedings in the swim bladder, muscles and other organs. Lack of some signs or their slight pronouncement do not exclude the need for laboratory examination. Variations and differences of disease signs in a population should be encompassed by a selection of separate samples, and all affected species should be sampled. Whole fishes near death or freshly dead specimens should be chilled and immediately delivered to a specialized or authorized laboratory.

Spring viremia of carp is listed as a notifiable disease by the OIE (see www.oie.int). Diagnostic procedures should be based on the OIE guidelines (Office International des Epizooties 2000). Etiological diagnosis of SVC is secured by the proof of virus presence in tissue sample using electron microscopical techniques, cryostat thin section immunofluorescence, or isolation of the agent. For the latter, cell lines such as FHM or EPC are recommended by the OIE. Cell monolayers are inoculated with 10 -fold dilutions of homogenates of kidney, spleen, liver and encephalon. Infected cell cultures incubated at $20^{\circ} \mathrm{C}$ usually show cytopathogenic effects after 24 to $48 \mathrm{~h}$. The virus yield in the internal organs can vary between $10^{4}$ to $10^{7} \mathrm{TCID}_{50}$ $\mathrm{ml}^{-1}$, depending on the phase of disease development. The isolated virus can be identified by serological techniques such as the serum neutralization test (NT), immunofluorescence (IF), immunoperoxidase (IP), or enzyme linked immunosorbent assay (ELISA) (Ahne 1981, Faisal \& Ahne 1984, Jørgensen et al. 1989, Way 1991, Rodak et al. 1993), although the antiserum used must be of high quality (Dixon \& Hill 1984). In routine diagnostics, immunohistological techniques using virus-infected cell cultures or a cryostat thin section of infected organs are generally considered to be the most reliable and convenient techniques for virus identification. Fundamental reagents are standard antigen (SVCV reference strain ATCC VR-1390, Fijan et al. 1971) and polyclonal, or preferably monoclonal, antibodies (BIO-FLOU SVC, Bio-X, 30 Hoogveldiaan, 1700 Dilbeek, Belgium). SVCV is serologically distinct from the other known fish rhabdoviruses, with the exception of PFR that cross-reacts with SVCV by immunofluorescence and ELISA (Jørgensen et al. 1989, Way 1991). The indirect diagnosis of SVCV is based on detection of virus-specific antibodies in the fish serum. For seroepidemiological surveys, NT, IF or ELISA are usually used. The immune status of investigated fish revealed a high incidence of serologically positive carp farms in Europe (Ahne 1979, Dixon et al.
1994). As already described above, SVCV shares antigenic determinants with PFR (Jørgensen et al. 1989, Way 1991). SVCV and PFR cannot be reliably distinguished by certain serological approaches, especially IF and ELISA. Both rhabdoviruses are listed as tentative species in the genus Vesiculovirus of the Rhabdoviridae (Walker et al. 2000), but PFR is, in contrast to SVC, not an OIE notifiable agent. Therefore, proper methods should be used to distinguish between isolates of SVCV and PFR. A ribonuclease protection assay (RPA) was developed that can distinguish between SVCV and PFR (Ahne et al. 1998). Probes for the full-length G gene of SVCV were used successfully to discriminate 13 viruses from different teleost fishes cross-reacting in the SVCV/PFR-IF. In addition, RPA results revealed genetic diversity among SVCV isolates obtained from different carp species and different locations. Molecular methods for detection of SVCV are not widely used at present and are not included among the approved methods of the OIE. However, a semi-nested PCR has been established to identify the SVCV G gene in fish tissues (Liu et al. unpubl.). This could be a method to screen for SVCV in chronic or persistently infected fish or in fish that are carriers of the virus. As RNA viruses usually form 'quasi-species' that include wide genomic variation, some genotypes will only have a selective advantage if growth conditions change (Steinhauer \& Holland 1987). Oreshkova et al. $(1995,1999)$ used the reverse transcriptase PCR (RT-PCR) developed for the M and G gene and hybridization with non-radioactive probes for detection of SVCV. Biotinylated probes used for hybridization were $248 \mathrm{bp}$ fragments of the M gene. Dot blots gave sensitive virus specific signals in tissue samples of experimentally infected carp fingerlings if the virus titers were approximately $10^{5} \mathrm{TCID}_{50} \mathrm{~g}_{\text {tissue }}{ }^{-1}$. Reagents for SVCV diagnosis can be obtained from the OIE reference laboratory for SVCV. ${ }^{1}$

\section{PROPHYLAXIS AND CONTROL OF SVC}

Temperatures above $20^{\circ} \mathrm{C}$ usually secure in carp a level of metabolic activity that enables production of protective levels of interferon (Baudouy 1978) and antibodies (Ahne 1980). Therefore, SVC-diseased fish have so far not been reported in tropical and subtropical climates. In rearing facilities with a controlled environment, elevation of temperature can prevent or stop SVC outbreaks. In temperate climates, avoidance and eradi-

\footnotetext{
${ }^{1}$ The Centre for Environment, Fisheries \& Aquaculture Sciences, Weymouth Laboratory, Barrack Road, The Nothe, Weymouth, Dorset DT4 8UB, UK (b.j.hill@cefas.co.uk)
} 
cation seem possible on modern small farms using spring or well water. On large carp farms, general prevention and control measures have little chance of being effective. Location of farms on, and connections with, large surface water systems make it impossible to prevent natural movements of carriers such as carp and perhaps other fishes from farms to open waters and back. Selection, hybridization and genetic manipulation of carp for SVC resistance has not yet resulted in a tested and accepted strain. This approach to prevention has a long tradition in Russia. Kirpichnikov et al. (1987) reported results of strain selection, and Wolf (1988, p. 191-216) mentioned the highly touted resistance of the Krasnodar strain, but data on controlled challenges of such carp strains are still lacking. Effective and safe immunoprophylaxis has not been established yet. However, carp vaccinated intraperitoneally or orally in autumn with live virus can develop a solid resistance to reinfection, which can last several months including overwintering (Fijan et al. 1977a,b, Fijan 1988, 1999). A commercial inactivated SVCV preparation for intraperitoneal delivery gave positive results in vaccinations of carp in Eastern Europe (Tesarčik \& Macura 1981). A possible strategy of vaccination and the existing limitations were reported (Fijan \& Matašin 1980, Fijan 1984). Any type of vaccine should preferably be delivered at water temperatures above 19 to $20^{\circ} \mathrm{C}$. Broodfish can be vaccinated immediately after spawning. The 40 to $60 \mathrm{~d}$ old fry could be immunized by bath or orally. For fingerlings in early autumn, only oral delivery is possible in the present carp production technology. Depending upon local economic conditions, the intraperitoneal vaccination of $2 \mathrm{yr}$ old carp for stocking in spring may be advantageous. More research is needed for setting up models and standards for vaccine development and for their testing in aquaculture. Although DNA vaccines show great promise for use against VHSV and IHNV (Lorenzen et al. 1999, Corbeil et al. 2000), an efficacious DNA vaccine against SVCV has not yet been reported, due at least in part to the difficulty of the live-fish challenge-model in carp. However, experiments showed that plasmid DNA encoding the SVCV glycoprotein elicited a non-specific, protective immunity against the salmonid rhabdovirus IHNV in rainbow trout (Kim et al. 2000). The nature of vaccines used in the future (mono- or polyvalent live or inactivated virus, subunit vaccine, DNA vaccine) will depend upon effectiveness, safety, current legislation, and upon the local epizootiological situation.

\section{LITERATURE CITED}

Ahne W (1973) Zellkulturen aus verschiedenen Süsswasserteleosteergeweben und Untersuchungen über die Ätiologie der Schwimmblasenentzündung der Karpfen. PhD thesis, Ludwig-Maximilians Universität, Munich
Ahne W (1976) Untersuchungen über die Stabilität des karpfenpathogenen Virusstammes 10/3. Fisch Umwelt 2: 121-127

Ahne W (1977) Evidence for the systemic character of Rhabdovirus carpio infection. Bull Off Int Épizoot 87:435-436

Ahne W (1978) Uptake and multiplication of spring viremia of carp virus in carp, Cyprinus carpio L. J Fish Dis 1:265-268

Ahne W (1979) Untersuchungen über die akute Form der infektiösen Bauchwassersucht bei Cypriniden (Cyprinus carpio, Ctenopharyngodon idella). Veterinärmedizinische Habilitationsschrift, Ludwig-Maximilians Universität, Munich

Ahne W (1980) Rhabdovirus carpio-Infektion beim Karpfen (Cyprinus carpio): Untersuchungen über Reaktionen des Wirtsorganismus. Fortschr Vet 30:180-183

Ahne W (1981) Serological techniques currently used in fish virology. Dev Biol Stand 49:3-27

Ahne W (1982) Vergleichende Untersuchungen über die Stabilität von vier fischpathogenen Rhabdoviren (VHSV, PFR, SVCV, IPNV). Zentralbl Veterinärmed 29:457-476

Ahne W (1985a) Argulus foliaceus L. and Piscicola geometra L. as mechanical vectors of spring viraemia of carp virus (SVCV). J Fish Dis 8:241-242

Ahne W (1985b) Viral infection cycles in pike (Esox lucius L.). J Appl Ichthyol 1:90-95

Ahne W (1986) The influence of environmental temperature and infection route on the immune response of carp (Cyprinus carpio) to spring viremia of carp virus. Vet Immunol Immunopathol 12:383-386

Ahne W, Wolf K (1977) Spring viremia of carp. US Department of Interior, Fish Disease Leaflet. Fish Wildl Serv 51:1-11

Ahne W, Kurath G, Winton JR (1998) A ribonuclease protection assay can distinguish spring viremia of carp virus from pike fry rhabdovirus. Bull Eur Assoc Fish Pathol 18: $220-224$

Arshaniza NM, Bauer ON, Vladimirov VL (1968) Air bladder disease of carps: its aetiology, epizootiology and control. Bull Off Int Épizoot 69:999-1006

Bachmann PA, Ahne W (1973) Isolation and characterization of agent causing swim bladder inflammation of carp. Nature 244: 235-237

Bachmann PA, Ahne W (1974) Biological properties and identification of the agent causing swim bladder inflammation in carp. Arch Ges Virusforsch 44:261-269

Baudouy AM (1975) Virémie printanière de la carpe: premiers isolements du virus en France. Bull Off Int Épizoot 83: 717-722

Baudouy AM (1978) Relation hôte-virus au cours de la virémie printanière de la carpe. CR Acad Sci Paris 286:1225-1228

Baudouy AM, Danton M, Merle G (1980a) Virémie printanière de la carpe: étude experimentale de l'infection évoluant a différentes temperatures. Ann Virol (Paris) 131E:479-488

Baudouy AM, Danton M, Merle G (1980b) Virémie printanière de la carpe: résultats de contaminations experimentales effectuées au printemps. Ann Res Vét 11:245-249

Bauer ON, Faktorovich KA (1969) Research on infectious diseases of carp in the USSR. Bul VURH Vodnany 5(3):30-43

Békési L, Csontos L (1985) Isolation of spring viraemia of carp virus from asymtomatic broodstock carp, Cyprinus carpio L. J Fish Dis 8:471-472

Bishop DHL, Smith MS (1977) Rhabdoviruses. In: Nayak DP (ed) The molecular biology of animal viruses. Marcel Dekker, New York, p 167-280

Bjorklund HV, Emmenegger EJ, Kurath G (1995) Comparison of the polymerases (L genes) of spring viremia of carp virus and infectious hematopoietic necrosis virus. Vet Res 26:394-398 
Bjorklund HV, Higman KH, Kurath G (1996) The glycoprotein genes and gene junctions of the fish rhabdoviruses spring viremia of carp virus and hirame rhabdovirus: analysis of relationships with other rhabdoviruses. Virus Res 42:65-80

Bjorklund HV, Johansson TR, Rinne A (1997) Rhabdovirusinduced apoptosis in a fish cell line is inhibited by a human endogenous acid cysteine proteinase inhibitor. J Virol 71:5658-5662

Bootsma R, Fijan N, Blommaert J (1977) Isolation and preliminary identification of the causative agent of carp erythrodermatitis. Vet Arh 47:291-301

Bucke D, Finlay J (1979) Identification of spring viremia in carp (Cyprinus carpio) in Great Britain. Vet Rec 169:69-71

Bussereau F, de Kinkelin P, Le Berre M (1975) Infectivity of fish rhabdoviruses for Drosophila melanogaster. Ann Microbiol (Paris) 126A:389-395

Clark HF, Soriano EZ (1974) Fish rhabdovirus replication in non-piscine cell culture: new system for the study of rhabdovirus-cell interaction in which the virus and cell have different temperature optima. Infect Immun 10:180-188

Clerx JPM, Horzinek MC (1978) Comparative protein analysis of non-salmonid fish rhabdoviruses. J Gen Virol 40: 287-295

Corbeil S, La Patra SE, Anderson ED, Kurath G (2000) Nanogram quantities of a DNA vaccine to protect rainbow trout fry against heterologous strains of infectious hematopoietic necrosis virus. Vaccine 18:2817-2824

de Kinkelin P, Le Berre M (1974) Rhabdovirus des poissons. II. Proprietes in vitro du virus printaniere de la carpe. Ann Microbiol (Paris) 125A:113-124

de Kinkelin P, Le Berre M, Lenoir G (1974) Rhabdovirus des poissons. I. Proprietes in vitro du virus de la maladie rouge de l'alvin de brochet. Ann Microbiol (Paris) 125A:93-111

Dixon PF, Hill BJ (1984) Rapid detection of fish rhabdoviruses by the enzyme-linked immunosorbent assay (ELISA). Aquaculture 42:1-12

Dixon PF, Hattenberger-Baudouy AM, Way K (1994) Detection of carp antibodies to spring viraemia of carp virus by a competitive immunoassay. Dis Aquat Org 19:181-186

Faisal M, Ahne W (1984) Spring viremia of carp virus (SVCV): comparison of immunoperoxidase, fluorescent antibody and cell culture isolation techniques for detection of antigen. J Fish Dis 7:57-64

Faisal M, Ahne W (1990) A cell line (CLC) of adherent peripheral blood mononuclear cells of a normal common carp (Cyprinus carpio). Dev Comp Immunol 14:255-260

Fijan N (1972) Infectious dropsy in carp-a disease complex. In: Mawdesley-Thomas LE (ed) Diseases of fish. Symposia of the Zoological Society of London, London, p 39-51

Fijan N (1984) Vaccination of fish in European pond culture: prospects and constraints. Symp Biol Hung 23:233-241

Fijan N (1988) Vaccination against SVCV. In: Ellis AE (ed) Fish vaccination. Academic Press, London, p 204-215

Fijan N (1999) Spring viremia of carp and other viral diseases of warm-water fish. In: Woo PTK, Bruno DW (eds) Fish diseases and disorders, Vol 3. CAB International, Oxon, p $177-244$

Fijan N, Matašin Ž (1980) Spring viraemia of carp: preliminary experiments on vaccination by exposure to virus in water. Vet Arh 50:215-220

Fijan N, Petrinec Z, Sulimanović Đ, Zwillenberg LO (1971) Isolation of the viral causative agent from the acute form of infectious dropsy of carp. Vet Arh 41:125-138

Fijan N, Petrinec Z, Štancl Z, Dorson M, Le Berre M (1977a) Hyperimmunization of carp with Rhabdovirus carpio. Bull Off Int Épizoot 87:439-440

Fijan N, Petrinec Z, Štancl Z, Kezić N, Teskeredžic E (1977b)
Vaccination of carp against spring viremia: comparison of intraperitoneal and peroral application of live virus to fish kept in ponds. Bull Off Int Épizoot 87:441-442

Fijan N, Sulimanović Đ, Bearzotti M, Mužinić D, Zwillenberg LO, Chilmonczyk S, Vautherot JF, de Kinkelin P (1983) Some properties of the epithelioma papulosum cyprini (EPC) cell line from carp Cyprinus carpio. Ann Inst Pasteur Virol 134E:207-220

Fijan N, Matašin Ž, Jeney Z, Olah A, Zwillenberg LO (1984) Isolation of Rhabdovirus carpio from sheatfish (Silurus glanis) fry. Symp Biol Hung 23:17-24

Ghittino P, Beccaria E, Ferrari A (1971) Caso die ascite infectiva della carpa modernamente diagnosticato anche in Italia. Riv Ital Piscicolt Ittiopatol A XV:1-4

Gravell M, Malsberger RG (1965) A permanent cell line from fathead minnow (Pimephales promelas). Ann NY Acad Sci 126:555-565

Gupta KC, Bishop DA, Roy P (1979) 5`-terminal sequences of spring viremia of carp virus RNA synthesized in vitro. J Virol 30:735-745

Haenen OLM, Davidse A (1993) Comparative pathogenicity of two strains of pike fry rhabdovirus and spring viremia of carp virus for young roach, common carp, grass carp and rainbow trout. Dis Aquat Org 15:87-92

Hill BJ, Underwood BO, Smale CJ, Brown F (1975) Physicochemical and serological characterization of 5 rhabdoviruses infecting fish. J Gen Virol 27:369-378

Hofer B (1904) Handbuch der Fischkrankheiten. Verlag der Allgemeinen Fischerei-Zeitung, B. Heller, Munich

Hoffmann B, Schutz H, Mettenleiter T (2002) Determination of the complete genomic sequence and analysis of the gene products of the virus of spring viremia of carp, a fish rhabdovirus. Virus Res 84:89-100

Johansson T (2001) Fish pathogenic rhabdoviruses, molecular characterization, phylogeny and inhibition of virusinduced apoptosis by cysteine proteinase inhibitors. Virus Res 80:11-22

Johnson MC, Maxwell JM, Loh PC, Leong JA (1999) Molecular characterization of the glycoproteins from 2 warm water rhabdoviruses: snakehead rhabdovirus (SHRV) and rhabdovirus of penaeid shrimp RPS/spring viremia of carp virus (SVCV). Virus Res 64:95-106

Jørgensen PEV, Olesen NJ, Ahne W, Lorenzen N (1989) SVCV and PFR viruses: serological examination of 22 isolates indicates close relationship between the two fish rhabdoviruses. In: Ahne W, Kurstak E (eds) Viruses of lower vertebrates. Springer Verlag, Heidelberg, p 349-366

Kaattari SL, Piganelli JD (1996) The specific immune system: humoral defense. In: Iwama G, Nakanishi T (eds) The fish immune system, organism, pathogen, and environment. Academic Press, San Diego, p 207-254

Kelly JM, Emerson SU, Wagner RR (1972) The glycoprotein of vesicular stomatitis virus is the antigen that gives rise to and reacts with the neutralizing antibody. J Virol 10: 1231-1235

Kim CH, Johnson MC, Drennan JD, Simon BE, Thomann E, Leong JC (2000) DNA vaccines encoding viral glycoproteins induce nonspecific immunity and Mx protein synthesis in fish. J Virol 74: 7048-7054

Kirpichnikov VS, Iliasov JJ, Schart LA, Ganchenko IV (1987) Selection of carp strains resistant to dropsy. Proc Zool Inst USSR Acad Sci (Dokl Zool Inst Akad Nauk SSR Leningrad) 171:35-46 (in Russian)

Kiuchi A, Roy P (1984) Comparison of the primary sequence of spring viremia of carp virus $M$ protein with that of vesicular stomatitis virus. Virology 134:238-243 
Kölbl O (1975) Neue Erkenntnisse über die Bauchwassersucht bei Karpfen. Oesterr Fisch 28:69-72

Kurath G, Higman KH, Bjorklund HV (1997) Distribution and variation of NV genes in fish rhabdoviruses. J Gen Virol 78:113-117

Lenoir G (1973) Structural proteins of spring viremia of carp. Biochem Biophys Res Commun 51:895-899

Lenoir G, de Kinkelin P (1975) Fish rhabdoviruses: a comparative study of protein structure. J Virol 16:259-262

Lorenzen N, Lorenzen E, Einer-Jensen K, Heppell J, Davies H (1999) Genetic vaccination of rainbow trout against viral hemorrhagic septicemia virus: small amounts of plasmid DNA protect against a heterologous serotype. Virus Res 63:9-25

Lu Y, Loh PG (1994) Infectivity studies of rhabdovirus in the penaeid blue shrimp. Aquacult Int 2:123-127

Lu Y, Nadala ECB, Brock JA, Loh PC (1991) A new virus isolated from infectious hypodermal and hematopoietic necrosis virus (IHHNV)-infected penaeid shrimps. J Virol Methods 31:189-196

Marcotegui MA, Estepa A, Frias D, Coll JM (1992) First report of a rhabdovirus affecting carp in Spain. Bull Eur Assoc Fish Pathol 12:50-53

Negele RD (1977) Histopathological changes in some organs of experimentally infected carp fingerlings with Rhabdovirus carpio. Bull Off Int Épizoot 87:449-450

Office International des Épizooties (2000) Spring viremia of carp. In: Diagnostic manual for aquatic animal diseases, 3rd edn. Office International des Épizooties, Paris, p 46-52

Oreshkova SF, Tikunova NV, Shchelkunov IS, Ilyichev AA (1995) Detection of spring viremia of carp virus by hybridization with biotinylated DNA probes. Vet Res 26: 533-537

Oreshkova SF, Shchelkunov IS, Tikunova NV, Shchelkunova TI, Puzyrev AT, Ilyichev AA (1999) Detection of spring viremia of carp virus isolates by hybridization with nonradioactive probes and amplification by polymerase chain reaction. Virus Res 63:3-10

Osadchaya EF (1964) Isolation of cytopathogenic agents from carp in the acute form of infectious dropsy of carp. Veterinarya (Mosc) 41:29

Otte E (1972) Die Schwimmblasenentzündung der Karpfen (Aerocystis). Vet Med Nachr 4:331-339

Peters F, Neukirch M (1986) Transmission of some fish pathogenic viruses by the heron, Ardera cinerea. J Fish Dis 9: 539-544

Pfeil-Putzien C (1977) New results in diagnosis of spring viremia of carp caused by experimental transmission of Rhabdovirus carpio with carp louse (Argulus foliaceus). Bull Off Int Épizoot 87:457

Poch O, Blumberg BM, Bougueleret., Tordo N (1990) Sequence comparison of 5 polymerases (L proteins) of unsegmented negative strand RNA viruses: theoretical assignment of functional domains. J Gen Virol 71:1153-1162

Rodak L, Pospisil Z, Tomanek J, Vesely T, Obr T, Valicek L (1993) Enzyme-linked immunosorbent assay (ELISA) for the detection of spring viremia of carp virus (SVCV) in tissue homogenates of the carp. J Fish Dis 16:101-111

Roudikov NI (1980) La virose printaniere des poissons en URSS. Bull Off Int Épizoot 92:1069-1077

Roy P (1981) Phosphoproteins of spring viremia of carp virus. Virology 112:274-281

Editorial responsibility: Jo-Ann Leong

Corvallis, Oregon, USA
Roy P, Clewley JP (1978) Spring viremia of carp RNA and virion-associated transcriptase activity. J Virol 25:912-916

Roy P, Gupta KC, Kiuchi A (1984) Characterization of spring viremia of carp virus mRNA species and the 3' sequence of the viral RNA. Virus Res 1:189-202

Schäperclaus W (1930) Pseudomonas punctata als Krankheitserreger bei Fischen. Untersuchungen über Süsswasseraalrotseuche, Leibeshöhlenwassersucht der Cypriniden, insbesondere des Karpfens, und Fleckenseuche der Weißfische. Z Fisch 28:289-370

Shchelkunov IS, Shchelkunova TI (1989) Rhabdovirus carpio in herbivorous fishes: isolation, pathology and comparative susceptibility of fishes. In: Ahne W, Kurstak E (eds) Viruses of lower vertebrates. Springer Verlag, Heidelberg, p 333-348

Sokol F, Koprowski H (1975) Structure, function and mode of replication of animal rhabdoviruses. Proc Nat Acad Sci USA 72:933-936

Spiropoulou CF, Nichol ST (1993) A small highly basic protein is encoded in overlapping frame within the $\mathrm{P}$ gene of vesicular stomatitis virus. J Virol 67:3103-3110

Steinhauer DA, Holland JJ (1987) Rapid evolution of RNA viruses. Annu Rev Microbiol 41:409-434

Sulimanović Đ (1973) Immunity of carp to Rhabdovirus carpio and determination of antibodies by indirect hemagglutination. Vet Arh 43:153-161

Swofford DL (2000) PAUP*: phylogenetic analysis using parsimony and other methods (software). Sinauer Associates, Sunderland, MA

Tesarčik J, Macura B (1981) Field carp vaccination against spring viremia on the fish farms of the State Fishery. Pr VURH Vodnany (in Czech) 17:3-11

Tesarčik J, Macura B, Dedek L, Valiček L, Smid B (1977) Isolation and electron microscopy of a rhabdovirus from the acute form of infectious dropsy of carp (spring viremia of carp). Zentralbl Veterinärmed 24:340-343

Thompson JD, Gibson TJ, Plewniak F, Jeanmougin F, Higgins DG (1997) The ClustalX-Windows interface: flexible strategies for multiple sequence alignment aided by quality analysis tools. Nucleic Acids Res 25:4876-4882

Tomašec I, Brundnjak Z, Fijan N, Kunst L (1964) Weiterer Beitrag zur Ätiologie der infektiösen Bauchwassersucht des Karpfens. Bull Int Jugoslavenska Akademija Znanosti Umjetnosti Zagreb 16:35-44

Walker PJ, Benmansour A, Calisher CH, Dietzgen R and 7 others (2000) Family Rhabdoviridae. In: van Regenmortel MHV, Fauquet CM, Bishop DHL, Carstens EB and 7 others (eds) The Seventh Report of the International Committee for Taxonomy of Viruses. Academic Press, San Diego, CA, p 563-583

Way K (1991) Rapid detection of SVC virus antigen in infected cell cultures and clinically diseased carp by the enzymelinked immunosorbent assay (ELISA). J Appl Ichthyol 7: 95-107

Wolf K (1988) Fish viruses and fish viral diseases. Cornell University Press, Ithaca, NY

Wu JG, Kiuchi A, Roy P (1987) Intergenic sequences and gene-order (NMG) of SVCV. In: Mahy BWJ, Kolakofsky D (eds) The biology of negative strand viruses. Elsevier, Amsterdam, p 221-226

Wunner WH, Calisher CH, Dietzgen RG, Jackson AO and 7 others (1995) Rhabdoviridae. Arch Virol (Suppl) 10:275-288

Submitted: November 26, 2001; Accepted: June 27, 2002

Proofs received from author(s): November 21, 2002 